\title{
急性期頸髄損傷例における人工呼吸からの離脱因子
}

\author{
福田文雄* 植田 尊善*
}

\section{Factors of Weaning from Mechanical Ventilation in Acute Spinal Cord Injured Patients}

\author{
Fumio Fukuda, ${ }^{*}$ Takayoshi UeTA*
}

\begin{abstract}
The purpose of this study is to investigate the factors of weaning from the mechanical ventilation in acute cervical spinal cord injured patients. In 41 acute tetraplegic patients required mechanical ventilator the tracheotomy was performed in our hospital from 1990 to 1998. Bony injury such as fracture or dislocation were seen in 23 patients, while no bony injuries in 18 patients. All bony injuries were stabilized by surgery, while patients without bony injuries were conservatively treated. 7 patients were died with respirator and 7 patients are alive with respirator and the remaining 27 patients are alive without respirator. So $66 \%$ of the patients required mechanical ventilator could get complete weaning. Its mean period until weaning was 45.6 days. Neurological level of each patients, C2 or $3: 4 / 4(100 \%), \mathrm{C} 4: 7 / 26(27 \%), \mathrm{C} 5: 3 / 8(38 \%)$ were died or did not get weaning and all $\mathrm{C} 6$ and $\mathrm{C} 7$ patients got weaning. It did not affect success of weaning whether the patients were surgically treated or not, whether bony injury was found or not, or whether paralysis was complete or not. Neither did the arterial blood gas, heart rate, nor vital capacity on admission. The sole factor that had influenced on weaning was the neurological level of injury. (Jpn J Rehabil Med 1999; 36 : 485-488)
\end{abstract}

要 旨：呼吸不全をともなった急性期頸髄損傷例の人工呼吸からの離脱について検討した。 対象は 1990〜1998 年に気管切開を行った 53 例のうち人工呼吸を必要とした 41 例（骨傷あ り：23 例，なし：18 例）とした。骨傷のある場合は整復固定術を，非骨傷例では保存療法を 原則とした． 7 例が死亡， 7 例が離脱不能，残り 27 例 $(66 \%)$ は平均 45.6 日で人工呼吸から 離脱した。離脱に関して手術・骨傷の有無, 入院時動脈血ガス分析, 心拍数, 肺活量, 完全麻 痺か否かは重要ではなかった。 C3 以上全例 (4 例), C4：26 例中 7 例, C5 $: 8$ 例中 3 例が死 亡または離脱不能であり唯一損傷高位が関与しており, 高齢, 合併症が呼吸機能を悪化させて いた。（リハ医学 $1999 ; 36: 485^{-488 ） ~}$

Key words : 頸髄損傷 (cervical spinal cord injury), 呼吸管理 (respiratory management), 人工呼吸 (mechanical ventilation), 離脱 (weaning)

はじめに

頸髄損傷の急性期における死亡原因の第 1 位は呼吸 不全である，呼吸障害の主因は呼吸筋麻痺によるもの であり, 吸気筋で最大とされる横隔膜は一般に C4 支 配とされ，C3 以上で頸髄が損傷されれば横隔膜呼吸
は消失し, 補助呼吸が必要となる。また C4 残存レべ ル以下では，吸気は自発的にできても，呼気筋（腹 筋, 内肋間筋）の麻痺によって咳嗽が不十分となり喀 痰排出が困難となる。また交感神経が遮断され迷走神 経が優位となり気道分泌が充進し, 低換気のため分泌 物は貯留し無気肺や肺炎が生じる ${ }^{1,2)}$.

1999 年 3 月 18 日受理, 1999 年 6 月 14 日受理

* 総合せき損センターリハビリテーション科/テ 820-8508 福岡県飯塚市大字伊岐須 550-4

Department of Rehabilitation, Spinal Injuries Center 
急性期の呼吸管理で重要なことは無気肺, 肺炎を予 防するための喀痰管理である、呼吸管理のために気管 切開が行われ, 必要に応じて人工呼吸器が装着され る. 一般に人工呼吸器の適応の目安としては呼吸数が 40 回/分以上, 一回換気量が $150 \mathrm{ml}$ 以下, 肺活量が $500 \mathrm{ml}$ 以下, $\mathrm{PCO}_{2}$ が $50 \mathrm{mmHg}$ 以上, 患者の疲労が 激しく呼吸苦が強い等があるが, 当センターでは麻痺 が C3 残存レベル以上, あるいは C4 残存レベル以下 でも肺活量が $500 \mathrm{ml}$ 以下の症例で呼吸困難を認めた 場合, 喀痰管理のため予防的に気管切開術を施行して いる.

$\mathrm{C} 4$ 以下の損傷の場合人工呼吸から離脱できるはず であるが, 必ずしも全例可能とは限らない. そこで急 性期頸髄損傷例において人工呼吸から離脱に関する因 子について検討した。

\section{対象と方法}

1990～1998 年に入院した急性期頸髄損傷例 383 例 のうち気管切開を行ったのは 53 例であり，そのうち 人工呼吸を必要とした 41 例 $(10.7 \%)$ を対象とした。 男性 37 例, 女性 4 例，平均年歯土標準偏差 $62.0 \pm$ 15.1 歳 (17〜85 歳), 受傷から入院まで期間は, 0 ～ 5 日：33 例，6 10 日：2 例，11 14 日：6 例，平均士 標準偏差 $2.95 \pm 3.8$ 日であった，治療は原則として骨 傷・脱臼がある場合入院後直ちに整復固定術を行い, 非骨傷・全身状態が不良の場合は保存療法を行った。

\section{表 1 改良 Frankel 分類}

A motor, sensory complete 運動・感覚とも完全麻痺

B motor complete, sensory only

B1 運動完全麻㽻 仙髄領域のみの触覚保存

B2 運動完全麻痺 仙髄領域だけでなく広範な範囲 で触覚保存

B3 運動完全麻痺 痛覚不全麻痺

C motor useless

C1 下肢筋力 $\quad 0 \sim 2$ (過半数以下の筋力が 2 以下)

C2 下肢筋力 $2 \sim 4$ (過半数以下の筋力が 2・3)

D motor useful

D0 下肢筋力は 4 5 あり歩行できそうであるが急性 期のためテスト困難

D1 屋内, 平地歩行 $100 \mathrm{~m}$, 屋外困難 下肢装具, 車 椅子併用

D2 杖, 下肢装具必要, 屋外歩行安定 車椅子不要 上肢機能障害があり部分介助必要 (中心性損傷)

D3 杖, 装具不要で完全独歩可能 上肢機能含めて 介助不要

E normal 筋力低下, 知覚障害なし (反射六進はあって よい)
手術： 20 例（後方固定術のみ 14 例, 前方固定兼後方 固定術 6 例)，保存：21 例であり，損傷形態は骨傷あ り：23 例（脱臼，亜脱臼，椎体骨折，脱臼後自然整 復 22 例, 歯突起骨折 1 例), 非骨傷：18 例であった。

入院時麻舫評価として当センターで考案した改良 Frankel 分類を用いると（表 1)，A：37 例，B2：3 例， $\mathrm{C} 1 ： 1$ 例であった。 入院時頸髄損傷高位（以下， 損傷高位) を残存する最下位で表す改良 Zancolli 分 類を用いると（表 2)，C1，2：2 例，C3：2 例，C4： 26 例, C5A：8例, C6B II $: 1$ 例, C7A：2例であっ た.

人工呼吸からの離脱の基準として, intermittent mandatory ventilation (IMV), pressure support ventilation（PS）などの補助呼吸法を行いながら， room air下での自発呼吸にて $\mathrm{PCO}_{2}$ が $50 \mathrm{mmHg}$ 以 下であれば離脱を試みた。

人工呼吸からの離脱に関する因子として，手術の有 無，損傷形態，損傷高位，room air下での入院時動 脈血ガス分析として酸素分圧 $\left(\mathrm{PO}_{2}\right)$ ，二酸化炭素分 圧 $\left(\mathrm{PCO}_{2}\right)$, 酸素飽和度 $\left(\mathrm{SaO}_{2}\right)$, 入院時心拍数, 肺 活量および完全麻痺か否かについて検討した．検定は $t$-検定および $\chi^{2}$ 検定を用い有意水準 $5 \%$ とした。

\section{結果}

41 例中 7 例は死亡し, 4 例は呼吸器のまま転院とな り，3 例は離脱不能のまま入院中であり，離脱不能例 は計 14 例（34\%）であった。 27 例（66\%）は平均 45.6 日（6２39 日）で人工呼吸から離脱した。離脱 までの期間は 2 週以内： 9 例， $2 \sim 4$ 週： 5 例， 4 週以 上：13 例であった.

入院時既に他医で挿管または気管切開が行われてい た 10 例は，酸素や昇圧剤が投与されていたため，入

表 2 改良 Zancolli 分類

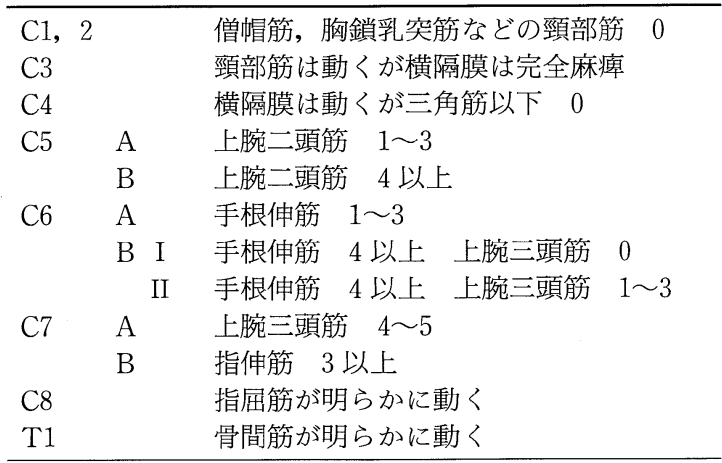


表 3 入院時動脈血ガス分析値 - 心拍数・肺活量

\begin{tabular}{lccc}
\hline & $\begin{array}{c}\text { 離脱可能群 } \\
(N=24)\end{array}$ & $\begin{array}{c}\text { 離脱不能群 } \\
(N=7)\end{array}$ & $p$ 值 \\
\hline $\mathrm{PO}_{2}(\mathrm{mmHg})$ & 64.6 & 68.9 & 0.42 \\
$\mathrm{PCO}_{2}(\mathrm{mmHg})$ & 42.7 & 35.3 & 0.14 \\
$\mathrm{SaO}_{2}(\%)$ & 91.5 & 92.6 & 0.65 \\
$\mathrm{HR}(/ \mathrm{min})$ & 59.0 & 60.7 & 0.68 \\
肺活量 $(\mathrm{ml})$ & 519 & 600 & 0.68 \\
\hline
\end{tabular}

他医 10 例を除く $N=31(t$-検定 $)$

表 4 手術の有無・骨傷の有無・麻痺重傷度と人工呼 吸加らの離脱との関係

\begin{tabular}{cccc}
\hline & 離脱可能 & 離脱不能 & 計 \\
\hline 手術療法 & 15 & 5 & 20 \\
保存療法 & 12 & 9 & 21 \\
計 & 27 & 14 & 41 \\
\hline$p=0.22\left(\chi^{2}\right.$ 検定 $)$ & & & \\
\hline 骨傷あり & 15 & 8 & 23 \\
骨傷なし & 12 & 6 & 18 \\
計 & 27 & 14 & 41 \\
\hline$p=0.92\left(\chi^{2}\right.$ 検定 $)$ & & & \\
\hline 完全麻痺 & 24 & 13 & 37 \\
不全麻 & 3 & 1 & 4 \\
計 & 27 & 14 & 41 \\
\hline 計 & & &
\end{tabular}

$p=0.68\left(\chi^{2}\right.$ 検定 $)$

院時動脈血ガス分析値, 心拍数, 肺活量の検査值は除 外した。入院時 $\mathrm{PO}_{2}, \mathrm{PCO}_{2}, \mathrm{SaO}_{2}$, 心拍数, 肺活量 の值は, むしろ離脱不能例の方が離脱可能例よりも検 査值は優れていたが, 両者間の差は有意ではなかった (表 3).

手術の有無と人工呼吸から離脱との関係では, 骨傷 があるのに全身状態が不良のため保存療法を行った 4 例を含めているため, 保存療法群に離脱不能例が多い が, 手術療法と保存療法との差は有意ではなかった。 同様に損傷形態も骨傷有無の両者間の差は有意ではな かった。また完全麻痺（Frankel A）と不全麻痺 (Frankel B, C) についても, 両者間の差は有意では なかった（表 4). 損傷高位については，C3 以上の上 位損傷全例に加え，C4 で 26 例中 7 例，C5A で 8 例 中 3 例が死亡または離脱不能であった。死亡，人工呼 吸からの離脱不能例は C5A 以上に限られていた（図 1). 死亡, 離脱不能例 14 例を検討すると, 高齢, 麻 痺上向, 肺疾患（気管支拡張症, 誤嬩性肺炎）や全身 合併症 (くも膜下出血, 消化管出血, 強直性脊椎炎, 等）を併発していた（表 5).

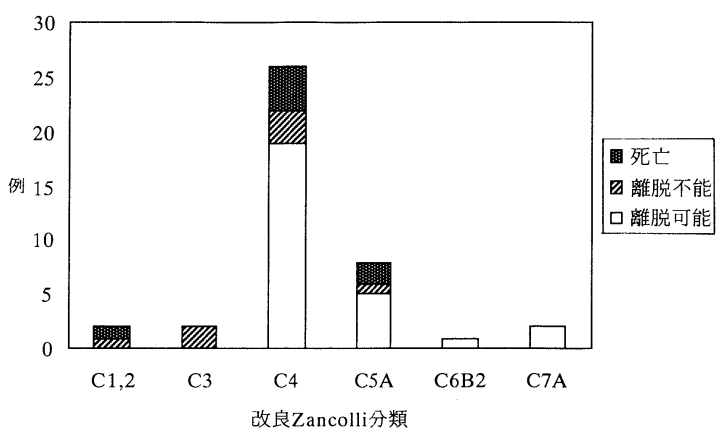

図 1 損傷高位と離脱との関係

$\mathrm{C} 3$ 以上全例, $\mathrm{C} 4: 7$ 例, $\mathrm{C} 5 \mathrm{~A}: 3$ 例が死亡または離脱不能 であった. 死亡, 離脱不能例は C5A 以上に限られていた。

\section{考察}

中下位頸髄損傷例において呼吸管理を長期化させる 原因として, 胸部外傷の重症度が関与しているとの報 告があるが3)，人工呼吸からの離脱因子に関する報告 は少ない.人工呼吸からの離脱不能の原因として(1)呼 吸筋麻痺, (2)呼吸器の器質的障害, (3)全身的合併症が 考えられる. 入院時動脈血ガス分析值, 心拍数, 肺活 量のそれぞれの值は, 入院時の呼吸状態を表している だけで，人工呼吸からの離脱やその後の呼吸機能の悪 化を予測できる指標にはなり得ないと考える．永山 ら ${ }^{3)}$ の報告と同じく, 手術の有無・損傷形態も人工呼 吸からの離脱に関与する因子ではなく, 本研究から損 傷高位が唯一重要な因子であった。

完全麻痺例は不全麻痺例と比較して呼吸障害が強い との報告がある ${ }^{4 \sim 6)}$. 離脱不能 14 例中 1 例のみが不全 麻痺であり，この症例は $\mathrm{C} 4$ まで麻痺が上向したため 呼吸不全となった（表 5). しかし人工呼吸からの離 脱に関しては, 脊髄横断面における完全損傷か否かは 重要でなく，あくまでも春髄矢状面における損傷高位 が関与している.

気管切開術後自発呼吸のみで十分な例や早期に人工 呼吸から離脱できた例では, 呼吸筋は十分に機能して いるのに対し, 何らかの補助呼吸が必要な例は, 自発 呼吸のみでは十分な換気量が得られない呼吸筋不全麻 痺の状態である. 離脱可能例は平均 45.6 日で離脱し ており, 自発呼吸のみで十分な換気量が得られるまで 受傷後 6〜 7 週を要することになる.この結果は最大 肺活量が得られるまでに 8～10 週を要するという報告 と同様 ${ }^{7,8)}$, 呼吸筋不全麻痺の回復を表している. 
表 5 死亡・離脱不能例 (14 例)

\begin{tabular}{|c|c|c|c|c|c|c|}
\hline \multicolumn{2}{|c|}{ 症例 } & Frankel & 損傷高位 & 骨傷の有無 & 合併症 & 転掃 \\
\hline 70 歳 & 男 & A & C5 A & C5/6・非骨傷 & 高齢，パーキンソン病 & 死亡 \\
\hline 50 歳 & 女 & A & $\mathrm{C} 4$ & C3/4 ・ 非骨傷 & くも膜下出血 & 死亡 \\
\hline 70 歳 & 女 & A & $\mathrm{C} 4$ & C3/4・非骨傷 & 高齢 & 死亡 \\
\hline 51 歳 & 男 & B2 & $\mathrm{C} 4$ & C5/6・亜脱臼 & 麻痺上向 & 死亡 \\
\hline 45 歳 & 男 & A & $\mathrm{C} 1,2$ & C3/4・亜脱臼 & 消化管出血・気胸 & 死亡 \\
\hline 82 歳 & 男 & A & $\mathrm{C} 4$ & C3/4・非骨傷 & 高齢，塵肺 & 死亡 \\
\hline 79 歳 & 男 & A & C5 A & C4/5・非骨傷 & 高齢 & 死亡 \\
\hline 57 歳 & 男 & A & C5 A & $\mathrm{C} 5 / 6$ ・脱臼 & 気管支拡張症 & 入院中 \\
\hline 85 歳 & 男 & A & $\mathrm{C} 4$ & $\mathrm{C} 4 / 5$ ・脱臼 & 高齢, 誤䀣性肺炎 & 入院中 \\
\hline 76 歳 & 男 & A & C3 & C3/4・非骨傷 & 高齢, 脳梗塞 & 入院中 \\
\hline 55 歳 & 男 & A & $\mathrm{C} 1,2$ & C3/4・非年傷 & 麻痺上向 & 転医 \\
\hline 17 歳 & 男 & A & $\mathrm{C} 4$ & $\mathrm{C} 3 / 4 \cdot$ 脱臼 & 無 & 転医 \\
\hline 69 歳 & 男 & A & C3 & 歯突起骨折 & 無 & 転医 \\
\hline 60 歳 & 男 & A & $\mathrm{C} 4$ & $\mathrm{C} 6 / 7$ ・脱臼 & 強直性脊椎炎, 麻痺上向 & 転医 \\
\hline
\end{tabular}

呼吸筋完全麻痺は一般に C3 以上の損傷高位といわ れている. 今回の結果では C3 以上の全例に加え， C4 では 26 例中 7 例，C5A では 8 例中 3 例が死亡または 離脱不能であった。C3，4レベルでも長期にみれば離 脱可能との報告はある ${ }^{9,10)}$ が，今回の受傷後経過期間 は，死亡例では平均 143 日（0４83 日), 離脱不能例 では平均 364 日（133〜697 日）であり，少なくとも この期間に扔いて何度か離脱を試みたが成功しなかっ た。

横隔神経は C3，4，5脊髄由来であるといわれてお

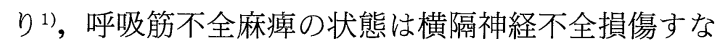
わち損傷高位でいう $\mathrm{C} 4, \mathrm{C} 5 \mathrm{~A}$ であると考えられる。 しかし C4，C5A の呼吸筋不全麻痺の全例が離脱でき ないわけではない. 自発呼吸のみでかろうじて換気し ている C4, C5A の呼吸筋不全麻痺の状態に, 高齢, 麻痺上向, 肺疾患, 全身合併症等の呼吸機能を悪化さ せる負の因子が加わると, 死亡または人工呼吸から離 脱できなくなると考えられる。

\section{ま と め}

急性期頸髄損傷例における人工呼吸からの離脱に関 する因子について検討した結果，手術の有無，損傷形 態, 入院時動脈血ガス分析值, 心拍数, 肺活量ならび に完全損傷か否かは，その因子ではなく，唯一損傷高 位が関与してお抢り C3 以上の上位損傷に加え，C4, C5A でも高齢または合併症が加われば，死亡または
人工呼吸から離脱できなくなると考えられる.

本論文の要旨は第 5 回日本りハビリテーション医学会九 州地方会に扔いて発表した。

\section{文献}

1) 有田秀穂: 呼吸器・循環器とリハビリテーション.リ 八医学 $1992 ; \mathbf{2 9}: 281-283$

2）鈴川正之: 春髄損傷 全身管理の進歩一特に呼吸管理 に関して一. 骨・関節・鞅帯 $1997 ; 10$ : 1417-1421

3）永山真理, 倉光せつ, 河田竜一, 黒田泰弘, 村川敏介：頸 骨有損傷完全麻痺患者に抢ける長期人工呼吸管理症例の 検討. 救急医 $1996 ; 7$ : 168-172

4) Lemonds VR, Wagner FC: Respiratory complications after cervical spinal cord injury. Spine 1994; 19: $2315-2320$

5）蔵本照雄, 上田聡子: 頸䯣損傷における呼吸不全例の 検討. 救急医 $1986 ; 10: 589-592$

6）内田直里, 吉田 哲, 福井哲郎, 永田義紀, 大谷美奈子: 頸髄損傷例に扔ける呼吸管理. 日災医誌 $1993 ; \mathbf{4 1}$ : 28-33

7) Cater RE: Medical management of complication of spinal cord injury. Adv Neurol 1979; 22 : 261-269

8) Cater RE : Respiratory aspects of spinal cord injury management. Paraplegia 1987 ; 25 : 262-266

9) Bach JR: Inappropriate weaning and late onset ventilatory failure of individuals with traumatic spinal cord injury. Paraplegia 1993; 31 : 430-438

10) Peterson $W$, Charlifue $W$, Gerhart $A$, Whiteneck $G$ : Two methods of weaning persons with quadriplegia from mechanical ventilators. Paraplegia 1994; 32 : 98-103 